\title{
НИТРОАЗОЛОПИРИМИДИНЫ - ПРИВИЛЕГИРОВАННЫЙ КЛАСС ГЕТЕРОЦИКЛОВ В МЕДИЦИНСКОЙ ХИМИИ
}

\author{
К.В. Саватеев', В.В. Федотов', С.К. Котовская', В.Л. Русинов'
}

1Уральский федеральный университет имени первого Президента России Б.Н. Ельцина, 620002, Россия, г. Екатеринбург, ул. Мира, 19.

DOI: 10.19163/MedChemRussia2021-2021-71

E-mail: i-krafttt@yandex.ru

Исследователи, работающие в области медицинской химии, стараются избегать использования соединений, содержащих нитрогруппу, поскольку этот функциональный фрагмент считается токсикофорным. С другой стороны, ранее было показано, что нитроазолотриазины проявляют высокую противовирусную активность вкупе с крайне низкой токсичностью $[1 \mathrm{a}, \mathrm{b}]$. Логично предположить, что соответствующие нитроазолопиримидины, как структурные аналоги, могут также являться ценными молекулами с полезной биологической активностью. Нами была разработана синтетическая методология ведущая к получению соответствующих нитроазолопиримидинов на основе коммерчески-доступных реагентов, а также возможности их дальнейшей структурной модификации для расширения спектра потенциального биологического действия.

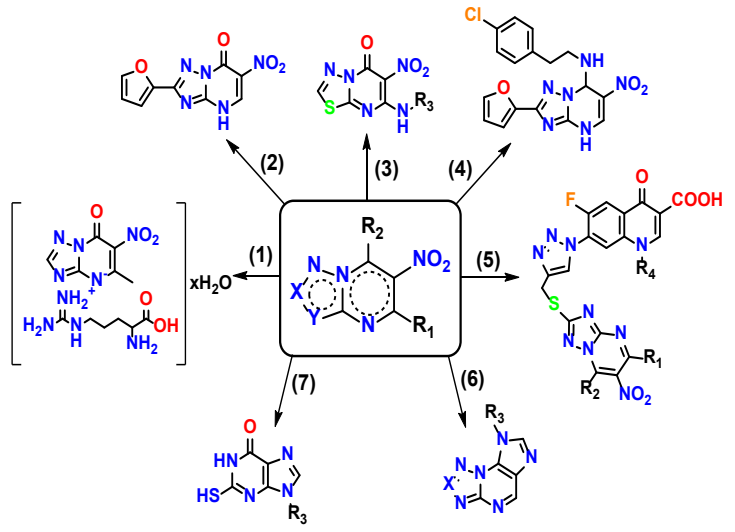

В результате этих работ было показано, что синтезированные гетероциклы обладают противовирусным действием invitro/invivo, противосептическим эффектом invivo, антигликирующей активностью invitro/exvivo, а также данные нитротриазолопиримидины являются близкими структурными аналогами эффекторов аденозиновых рецепторов, последние представляют собой привлекательную мишень для терапии опухолевых заболеваний.

Работа выполнена за счётСоглашения о предоставлении из федерального бюджета грантов в форме субсидий в соответствии с пунктом 4 статьи 78.1 Бюджетного кодекса Российской Федерации, г. Москва, «1» октября 2020 г. № 075-15-2020-777. 